\title{
Adalékok az információs társadalom és a civil szféra magyarországi viszonyához
}

A civil szféra fontos szerepet játszik az információs társadalom kialakulásában, és viszont: az információs társadalom kialakulásának fejleményei számos ponton kapcsolódnak a civil szférához, s így nagy számú civil szervezet érdeklődésének homlokterében állnak. A szerző az információs társadalommal közvetlenül érintkező szervezetek körében a közelmúltban végzett empirikus kutatás eredményeit ismerteti. A kutatás során az elméleti tájékozódás alapja Ernest Wilson gyémánt-modellje volt: következtetéseiben a szerző reflektál ennek használhatóságára és továbbgondolhatóságára a magyarországi viszonyok között.

\section{Szerzői információ:}

Füzesi Péter

Füzesi Péter szociológus hallgató az Eötvös Loránd Tudományegyetem társadalomtudományi karán, az ITTK külsố munkatársa. Kutatási területe a tudás és tudományszociológa, valamint a térfogalom társadalomelméleti változatai, illetve a fizikai tér társadalmi jelentôsége. A Zalai Béla Rendszerelméleti Társaság alapító tagja.

\section{Így hivatkozzon erre a cikkre:}

Füzesi Péter. „Adalékok az információs társadalom és a civil szféra magyarországi viszonyához”. Információs Társadalom V, 3. szám (2005): 63-81. https://dx.doi.org/10.22503/inftars.V.2005.3.5

A folyóiratban közölt müvek a Creative Commons Nevezd meg! - Ne add el! - Így add tovább! 4.0 Nemzetközi Licenc feltételeinek megfelelően használhatók. 
Füzesi Péter

\section{Adalékok az információs társadalom és a civil szféra magyarországi viszonyához ${ }^{1}$}

\section{Bevezetés: információs társadalom és civil szféra}

Az információs társadalom és a civil szféra viszonyának vizsgálatát mind az infokommunikációs technológiák alkalmazása, mind a civil társadalom szerepe felól legitim kérdések felvetése indokolja, amelyek mindkét oldalon a figyelem előterében állnak. Az egyik kérdés arra vonatkozik, hogy az új infokommunikációs eszközök használata hogyan változtatja meg a döntéshozatali eljárásokat a helyi és országos politikai és társadalmi ügyekben, és milyen teret ad az állampolgári kezdeményezések megvalósításának. Az erre adható válaszok a civil kezdeményezéseknek az interneten való burjánzásától a kibertér magányába burkolózó remeték szélsôségéig terjed, akik minden kapcsolatukat elvesztették a „való” világgal. A másik legitim kérdésfelvetés a civil társadalom szereplóire háruló feladatok vizsgálata: Hogyan támogathatják a civil szereplók az infokommunikációs eszközök elterjedésével járó modernizációt és a társadalom múködését segítő alkalmazások meghonosodását a magyar társadalomban? Milyen módon lehet óket úgy bevonni a döntések meghozatalába, hogy a leghatékonyabban tudják közvetíteni a sajátos civil erốforrásokat?

Az INFONIA Alapítvány 2005 tavaszán átfogó kutatást végzett a magyarországi civil szervezetek és az információs társadalommal kapcsolatos átalakulások témakörében. A kutatás során külön területként vizsgáltuk az információs társadalom kiépítésében közvetlenül érintett, illetve a diskurzusban aktívan részt vevő szervezeteket. A két szféra - az információs társadalom és a nonprofit szervezetek - határán egyébként jellemzóen kevés szervezet helyezkedik el. A kutatás során a szakmai-politikai fórumokon végzett munkájuk és úgynevezett „médiajelenlétük” alapján jelentősebbnek tartott csoportok közül választottunk ki huszonhét olyan szervezetet, amelyek az információs és kommunikációs technológiák alkalmazásában, illetve az erról folytatott diskurzusban markáns szerepet játszottak. ${ }^{2}$ Ezeket külön részkutatás keretében, szakértói interjúk keretében és a kvalitatív sajtóelemzés módszerével vizsgáltuk.

\section{Módszertani és elméleti megfontolások}

A kutatás során felkeresett szervezetek vizsgálatánál két módszert alkalmaztunk: egyrészt a szervezetek képviselôinek egyórás szakértôi mélyinterjúk során a szervezettel kapcsolatos és a magyar információs társadalom állapotát érintő kérdéseket tettünk

${ }^{1}$ A kutatásban Fonyó Attila, Kiss Mónika, Neltz Tamás és Szabó Elôd munkája segített. A tanulmány Pintér Róbert segítố támogatása nélkül nem jöhetett volna létre. Ezennel szeretnék mindenkinek köszönetet mondani.

${ }^{2}$ A 27 megkérdezett szervezet jegyzékét lásd a mellékletben. 
fel, másrészt pedig az elektronikus és a nyomtatott sajtóban 1994 óta megjelent és hozzáférhetố cikkek kvalitatív elemzésével elvégeztük a vizsgált szervezetek médiareprezentációjának rekonstrukcióját. Ez utóbbi elemzés fő célja annak a felmérése volt, hogy mely szervezetek milyen témákkal tudtak megjelenni a nyilvánosság előtt, és az információs és kommunikációs technológiákkal összefüggésben milyen nagyobb nyilvános vitákra került sor.

Az interjúk elemzésekor kétféle típusú információt különböztettünk meg:

- A szervezettel kapcsolatos tárgyi információkra vonatkozó kérdések egyértelmúen megválaszolhatók voltak.

- A szervezetek motivációjára abból következtethettünk, ahogyan a környezetüket értékelték és a saját szerepüket definiálták.

A második információs szinten az interjúk szövegeit mint a szervezetról szóló narratívákat dolgoztuk fel. Ilyen módon az interjúk alapján a következô jelentésrétegek tûnnek rekonstruálhatónak:

- Egyrészt láthattuk, hogy a különböző szervezetek képviselói hogyan írják le saját környezetüket, milyen fogalmakat használnak és azokat hogyan határozzák meg, illetve hogyan jellemzik (reprezentáció). Az ilyen szempontból végzett elemzés rávilágított arra, hogy a megkérdezettek hogyan értelmezik az információs társadalom fogalmát és hogyan látják az információs társadalom kiépítésének helyzetét Európában, továbbá képet adott arról is, hogy a civil szereplốk miképpen vélekednek a magyar információs társadalom egyes strukturális kérdéseiról (például a tartalomkínálatról).

- Másrészt kiderült, hogy az adott szervezet milyen viszonyokat alakított ki a környezetével és annak egyes szereplóivel (participáció).

A médiareprezentációt vizsgálva az egyes szervezeteknek a különbözó médiumokban való megjelenésén túl azt próbáltuk rekonstruálni, hogy melyek a legfontosabb diskurzusok, amelyekben az általunk vizsgált szervezetek megszólaltak. A ,nyilvánosság" tekintetében megkülönböztettük az elektronikus és a nyomtatott médiumokat, illetve a szakmai és a tömegsajtót. Az így kapott négy csoportba a következố módon soroltuk be az általunk vizsgált sajtótermékeket: a legszúkebb nyilvánosságot elérô elektronikus szakmai portálok közé a www.terminal.hu és a www.backslash.hu, a nyomtatott szakmai sajtó csoportjába pedig a Computerworld-Számítástechnika, az Internet Kalauz, valamint a Chip és a Byte magazin került. Az elektronikus tömegmédiumok közül a www.index.hu és a www.origo.hu portálokat vizsgáltuk. Ezek nem feltétlenül az olvasóik számát tekintve maradnak el a nyomtatott tömegsajtótól, hanem jellegükben térnek el attól, ugyanis fóként az internet iránt leginkább nyitott rétegeket, elsősorban a fiatalokat érik el. A legmagasabb szintû́ nyilvánosságot biztosító kategóriába sorolt médiumok közé a Népszabadság, a Magyar Nemzet, a Figyeló és a Heti Világgazdaság került.

A kutatás során az egyik legfontosabb elméleti tájékozódási pontot az Ernest Wilson nevéhez fúződő gyémánt-modell adta. Ez az egyes országok olyan modernizációs modelljét reprezentálja, amelynek alapja a fejlesztésben szerepet játszó négy fóbb aktor (a politika, a gazdaság, a tudomány és a civil szektor) teljesítménye és a közöttük létrejött együttmúködés minốsége. A modellt természetesen bizonyos fenntartásokkal 
kezeltük, hiszen azt Wilson eredetileg a fejlődó világban végzett kutatásai során dolgozta ki, jellemzóen az angolszász gondolkodásmód jegyében, s ezért egy volt államszocialista ország társadalmi viszonyaira nem ültethetôát maradéktalanul. A Wilson-gyémántban szereplő aktorokat kiegészítettük a médiával mint ötödik aktorral és az alábbiak szerint differenciáltuk:

- A politikai szférát részekre bontottuk, és külön kezeltük a központi kormányzati apparátust, amelynek legfontosabb feladata a tervezés, vagyis az információs társadalom kiépítése, valamint az államigazgatás szintjén megragadható adminisztrációt, amely az állampolgárok és a civil szervezetek számára megteremti a környezetet hivatalos ügyeik intézéséhez.

- A gazdasági szféra mint aktor változtatás nélkül átvehetố volt az eredeti modellból.

- Ezzel szemben a tudományos szféra szerepét már jelentốs mértékben újra kellett definiálnunk, hiszen Magyarországon mind az Akadémia és a hozzá tartozó kutatóhelyek, mind a felsőoktatási intézmények túlnyomórészt költségvetési intézmények, és mind önmeghatározásukat tekintve, mind tényleges múködésük gyakorlatában az állam alá rendelődnek.

- A civil szféra tekintetében abban a szerencsés helyzetben voltunk, hogy ez állt kutatásunk fó fókuszában, és a kérdéseket itt tehettük fel a legdifferenciáltabban. Noha egyértelmú volt számunkra, hogy a civil szféra Magyarországon sajátos módon szerveződik (elég csak a történelmi helyzetre gondolni), nem éltünk semmilyen konkrét elófeltevéssel vele kapcsolatban.

- A média mint aktor nem szerepel az eredeti wilsoni felosztásban, de könnyú belátni, hogy a társadalmi kommunikáció fő formájaként kiemelten fontos elemét képezi a civil szervezetek környezetének, ha azok artikulálni akarják céljaikat. A médiát ezért külön kutatási területként kezeltük.

Az alábbiakban a kutatási eredményeket a következố tagolásban ismertetem: Elôször az interjúk alapján rekonstruálható jelentésrétegeket mutatom be (reprezentáció és participáció), majd a vizsgált szervezetek médiareprezentációjának tanulságait ismertetem. Az utolsó részben kísérletet teszek arra, hogy összefoglaljam a szervezetek strukturális sajátosságait és reflektáljak a kutatás egészének eredményeire, továbbá kitérek a Wilson- gyémánt alkalmazhatóságára, valamint a tanulságok továbbgondolási lehetôségeire.

Az interjúk tanulságai: a magyar információs társadalom percepciója a megkérdezettek körében.

\section{Az információs társadalom fogalma}

Az interjúk elsố kérdései az információs társadalom mibenlétére vonatkoztak. A fogalom értelmezését illetôen a megkérdezett nonprofit szervezetek válaszaiból komplex és sokrétú kép bontakozik ki, ami magában foglalja nemcsak a technikai eszközökkel való ellátottságot, hanem a strukturális változásokat, a társadalom mú́ködéséhez szükséges egész feltételrendszert megváltoztató folyamatokat, a technikára ráépülő alkalmazásokat, valamint a technológiához kapcsolódó tudás és motiváció, az információs kultúra komplex rendszerét is. Ugyanakkor az információs 
társadalom fejlettségét többé-kevésbé jellemző módon azonosítják az internet penetrációs mérôszámával.

A megkérdezettek kiemelték, hogy az információs társadalom céljai és trendjei kevéssé jól ismertek, és a magyar közbeszédben a fogalom jelentése bizonytalan.

Jellemző, hogy a legtöbb civil szervezet elsôsorban a politikát és a gazdaságot nevezte meg olyan színtérként, ahol az információs társadalom trendjei érvényesülnek. Ezeken kívül visszatérố elem, hogy a megkérdezettek az információs társadalom fejlesztéséhez szükséges feltételrendszer megteremtését elsôsorban az államtól és a politikai erôktôl várják.

Az információs társadalom fogalmának értelmezése természetesen nemzetközi összehasonlításhoz kötődik: Magyarország ilyen szempontból a megkérdezettek szerint a középmezônyben, vagy az élbolyhoz képest még nagyobb lemaradásban van. Ugyanakkor, noha interjúalanyaink az Európai Uniót az információs társadalom szempontjából nemzetközi összehasonlításban nem tekintik centrumnak, Magyarország számára orientáló modellként elsôsorban európai országokat említettek. Úgy túnik, hogy Ázsia információs társadalmait illetốen a megkérdezettek vakfoltjára bukkanhatunk rá: mindössze egy válaszoló említett ázsiai példákat.

Az interjúkban megszólalók számára tehát az Európai Unió jelenti a legrelevánsabb összehasonlítási alapot, de a csatlakozás óta mind a Magyarországon kiépüló EUadminisztráció, mind a magyar (elsôsorban szakmai) nonprofit szervezetek számára nyitott EU-programok is jelentôs szerepet látszanak játszani már most is. Ehhez hozzájárul, hogy egyes szervezetek esetében az EU-csatlakozás lényeges javulást hozott a pályázati lehetôségek terén: több megkérdezett szervezet (MELASZ, MEKKE, MATISZ, MTE, INFÓRUM) már korábban bekapcsolódott az európai uniós programokba, illetve az európai szervezetek munkájába

A magyar információs társadalommal kapcsolatban jelzett gondok és problémák között elsốsorban a nyelvtudás hiánya, az alacsony penetráció, a nem megfelelő tartalomkínálat, valamint az internet-hozzáférés és a számítógépek magas költségei említhetók. A következókben az egyes aktorok szerint részletezve mutatom be az információs társadalom percepcióját.

\section{Állam}

Az állam és a politikai szféra megítélése - mivel ez a kérdés rendkívül széles kört fog át, sokszor eltérő helyzetben lévő aktorokkal - igen komplex. Ugyanakkor az összes megkérdezettre jellemzó, hogy az információs társadalommal kapcsolatos stratégia kialakítását és megvalósítását egyaránt az állami-politikai kompetenciák körébe sorolják. Az állami szféra teljesítményét a megkérdezettek általában a közepesnél rosszabbnak értékelték. A legtöbbször említett problémák a következók:

Az informatikai kormányzat „többfejû”, nem érvényesül egységes koordináció. Ehhez hozzájárul, hogy az információs társadalom fejlesztése tekintetében a kormány, illetve a közigazgatás nem minden tisztviselójében van meg a megfelelố tudatosság és motiváció, a fejlesztések sokszor szigetszerúen mennek végbe. 
Sok esetben problémát jelent az intézkedések átláthatatlansága és ellenôrizhetetlensége, és a közigazgatási szervek szintjén elófordul a technológia alkalmazására való felkészületlenség is. Többen említették a pénzalapok kevéssé hatékony és ellenốrizetlen elosztását, valamint a programok alacsony szintû́ integráltságát.

$\mathrm{Az}$ állam fontos, de eddig nem teljesített feladataként leggyakrabban az e-közigazgatás bevezetése került szóba. Mivel az e-kormányzat kérdését a legtöbb megkérdezett az információs társadalom fejlesztésének egyik stratégiai céljaként értelmezi, ezen a területen a jelenleginél jóval nagyobb aktivitást várnak a politikától. A másik stratégiai szempontból kitüntetett célként az innovatív szférákba, az oktatásba és a tudományba való befektetést jelölték meg. Az állami szerepvállalás elvárt területeként hasonló súllyal jelent meg továbbá a lakosság minél szélesebb körének bekapcsolása az internethasználatba.

További elvárásként fogalmazódott meg a Private Public Partnership (PPP) lehetôségeinek kihasználása, valamint az adó- és járulékterhek mérséklése a nemzetközi versenyképesség érdekében.

A szabad szoftverekkel foglalkozó szervezetekre jellemzó véleményként fogható fel, hogy az állam rossz múködésének szimptómái közé sorolják a nyílt forráskódú szoftverek elérhetetlenségét a közbeszerzésekben.

A közigazgatás tekintetében visszatérố vélemény, hogy a kapcsolatok kiemelt szerepet játszanak a hatékony szervezeti munkában. Ugyanakkor feltételezhető, hogy ez nem annyira a döntések befolyásolására, mint inkább az információszerzésre vonatkozik, és a nem kielégítốn informatív állami szféra egyik strukturális hiányosságának a kompenzációja.

\section{Az állammal kialakított kapcsolatok}

A megkérdezett civil szervezetek esetében az államhoz fúződő viszony három fő formája a támogatás, az együttmúködés és az érdekképviselet. Jellemző, hogy a költségvetési szervekhez kötôdő szervezetek az állammal való együttmúködés lehetôségeként egyedül az anyagi támogatást említik, és egyes esetekben magát az államot azonosítják azzal a szervvel, amellyel a pályázataik benyújtása során kapcsolatba kerülnek.

Az anyagilag valamelyest önálló, valamilyen gazdasági szervezetet a háta mögött vagy a tagjai között tudó, illetve valamilyen technológia hasznosításában tevékenykedő szervezetek elsốdleges célja a hatékony szakmai kommunikáció kialakítása az állammal. A kérdésról nyilatkozó szervezetek körében ezzel kapcsolatban a következô problémák merülnek fel:

- Intézményi szinten nem alakul ki hivatalos kommunikáció. Ugyanakkor az egyes személyek szintjén jó kapcsolatokat tudnak kialakítani: ez megerôsíti azt a megállapítást, hogy a szervezet sikeres menedzselésében kiemelten fontos a kapcsolati tóke szerepe.

- A civil szervezettekkel való kapcsolattartást a politika, illetve az állami szervek nem tartják megfelelóen fontosnak, a kommunikáció nem válik valóban hatékonnyá, mert az iteráció egy lépésben kimerül, vagyis a politika nem vár további visszacsatolásokat, és a vélemények egyeztetése után döntést hoz. 


\section{Gazdaság}

Az interjúkban a gazdaság kérdései már jóval kisebb gyakorisággal kerültek szóba. Nem túlságosan meglepó, hogy a gazdaságról elsốsorban a tagságukat a vállalatok köréból toborzó lobbiszervezetek alakítottak ki markáns képet, ami a következő állításokban foglalható össze:

A magyar informatikai ágazat fó problémája - a kis vállalatméretek mellett - a szféra alulintegráltsága, egyrészt az ágazaton belül, másrészt a kutatói oldallal és saját potenciális piacával fenntartott külsố kapcsolatok terén is, amit jól mutat, hogy a nem informatikai profilú cégeknél az IKT eszközök használata a kívánatosnál kisebb mértékben jellemző.

Az IKT szektorban nem eléggé elterjedt a különbözó projektkultúrák alkalmazása, és a vállalatok nem alkalmaznak minốsítési és fejlesztési keretrendszereket. Mindehhez hozzátartozik az innováció alacsony szintje, ráadásul a kis számú fejlesztés jelentốs részét külföldön értékesítik. Stratégiai célként fogalmazódott meg az innováció erősítése a gazdaságban az állam részéról történố támogatás eszközeivel is.

\section{Együttmüködés a gazdasággal}

A gazdasági szereplókkel kialakított kapcsolatok jó néhány szervezetnél alapvetôen meghatározó erejúek, hiszen a lobbitevékenységet folytató szervezetek az információs társadalommal foglalkozó NGO-k markáns csoportját alkotják.

A gazdasághoz fúzôdő viszony másik jellegzetes formáját a költségvetési intézményekhez kötődô civil szervezetek alakították ki: ezekre a korlátozott támogatói kapcsolat jellemző. A sikeres együttmúködés példájaként legtöbbször valamilyen ingyenes szolgáltatást említenek. Ugyanakkor ezek a szervezetek mint a vállalatok megrendelóinek a képviselói is megjelenhetnek, és a cégek támogatást nyújthatnak a szervezet múiködéséhez is.

Az alulról szerveződő, költségvetési intézményekhez nem kötődő civil kezdeményezések esetében a gazdasági szereplókkel való kapcsolatot-a szervezet kommunikációs felületén (mint reklámhordozón) keresztül - nagymértékben befolyásolja a szervezet nagysága, továbbá az is, hogy az általa véghezvitt konkrét projekt kötődik-e valamilyen módon az adott cég tevékenységéhez. Jellemzố panasz a civil szervezetek részéról, hogy önzetlen mecenatúra nem létezik. Ebból kiindulva úgy érzik, hogy a gazdasági szereplóket nem tekinthetik a múködésüket támogató komoly partnernek, s ezért az állami (illetve az Európai Unió által biztosított) pályázati források elérését tartják elsốrendú célnak. A cégekkel való kommunikációt ezen kívül természetesen befolyásolja a már említett kapcsolati tóke is.

A valamilyen informatikai technológiával vagy alkalmazással (pl. Linux, elektronikus aláirás, WiFi) foglalkozó nonprofit szervezetek rájuk jellemzó speciális viszonyrendszert alakítanak ki a cégekkel. A vállalatok közvetlen módon, akár tagsági viszonyon, akár szolgáltatások nyújtásán vagy eszközök rendelkezésre bocsátásán keresztül is bekapcsolódhatnak a szervezetek munkájába. Ezen kívül a civil szervezetek mint fejlesztók vagy mint szakmai kommunikációs partnerek is kapcsolatba kerülhetnek cégekkel. 


\section{Tudomány}

A tudományos szférával kialakított kapcsolatok szempontjából a megkérdezett szervezetek igen széles skálán mozognak: vannak olyan szervezetek, amelyek szorosan kötốdnek a tudomány világához, míg másoknak a tevékenysége egyáltalán nem érintkezik vele.

A tudományos szférával kapcsolatban az iparági érdekérvényesítố szervezetek részéról az alábbiak szerint összefoglalható markáns vélemény fogalmazódott meg: Ki kell dolgozni a tudomány és a gazdaság összekapcsolódásának a módjait, mert jelenleg nem múk ödik közöttük a technológiai transzfer. Biztosítani kell a kutatók motivációját, és erre építve fel kell lépni a kutatók itthon tartása érdekében. Az ehhez szükséges feltételrendszert az innovatív szférákban állami beruházás teremtheti meg. A továbbiakban a kutatókat érdekeltté kell tenni a gazdasághoz kapcsolódó fejlesztési munkában.

Ugyanakkor hangot adtak annak a véleménynek is, hogy az informatika jellegénél fogva olyan terület, ahol a fejlesztés nem igényel magasabb elméleti szintú tudományos kutatásokat, az innovációhoz szükséges alkalmazott kutatásokat pedig a cégek maguk is el tudják végezni (számos pályázatot nyújtanak be kisvállalatokon belüli kutatói hálózatok kiépítésére).

\section{Az NGO szektoron belüli kapcsolatok és a civil társadalomról alkotott kép}

Az interjúk alapján elmondható, hogy a szervezet jellege, a mások szemében róla kialakított kép és az, amit az egész szféráról gondolnak, ebben a kérdéskörben függ össze a legerôsebben. Mivel a megkérdezett NGO-k helyzetére és az általuk alkotott struktúrákra a késóbbiekben még kitérek, itt csak a szféra egészével kapcsolatban megfogalmazott véleményeket foglalom össze.

- A megkérdezett szervezetek jelentôs része lobbiszervezet, amely gazdasági szereplóket tömörít, és ennek megfelelốn a civil társadalomhoz képest valamelyest kívülállónak érzi magát. Egyébiránt jellemző, hogy a lobbiszervezetek egy része nyitott lenne az ,igazi” civilekkel való együttmúködésre, de fejletlennek tartja a civil szférát, amely ideális múködése esetén a „civil kontroll” érvényesítôje lehetne az állammal szemben.

- A költségvetési intézményekhez kötődő szervezetek bizonyos értelemben szintén elhatárolják magukat a civil szférától.

- A magyarországi civil társadalom történetének egyik legfontosabb szereplője a Soros Alapítvány, amely fiókszervezeteivel komoly katalizátorszerepet töltött be a magyarországi civil társadalomban. A NIOK és a C3 központ mint kvázi civil szervezetek direkt módon segítették és jelenleg is segítik a kisebb NGO-k informatikai felzárkózását, elsôsorban az információs szolgáltatások terén.

- Az alulról szervezódố civil szervezetek (pl. a zöldek, a szabad szoftverek szószólói és a feministák) jellemzóen erôs hálózatokkal rendelkeznek, de elsốsorban a saját területükön tevékenykedố más szervezetekkel alakítanak ki szoros kapcsolatokat. 
- A civilek anyagi lehetốségeivel kapcsolatban az alulfinanszírozottság a legtöbb interjúban direkt módon nem jutott kifejezésre, de többen szóvá tették, hogy az elnyert pályázati pénzösszegek késve érkeznek meg, és sok civil szervezet számára az utófinanszírozás is gondot jelent.

\section{A média megítélése és a médiakapcsolatok}

A megkérdezett civil szervezetek a médiával kapcsolatban egybehangzóan úgy vélekednek, hogy az internet magyarországi médiareprezentációján javítani kellene, mert a sajtóban jelenleg elsốsorban a negatívumok jelennek meg. Általánosnak tekinthetố vélemény továbbá az is, hogy noha a hagyományos médiumok e-mail útján való hozzáférhetốségük biztosításával, valamint a músorok és sajtótermékek online megjelenítésével elkezdték kiaknázni az internet adta lehetôségeket, a bennük rejlő felvilágosító-oktató potenciál nincs kihasználva.

A médiával kialakított viszony szorosan összefügg azzal, hogy a szervezet a saját tevékenységével mit szeretne elérni, és célcsoportjaként kiket definiál. A médiával kapcsolatos igények - és ténylegesen kihasznált lehetốségek - néhány esetben túlmutatnak a szervezetról való híradásokon, és jelentốs szerepet játszanak a szervezet imázsának kialakításában és promóciójában egyaránt.

A szervezetek vizsgálatakor megkülönböztettük, hogy a szervezet az adott médiummal belsố vagy külsố kommunikációt folytat-e. Belsố kommunikáción a szervezet potenciális támogatóival és az általa képviselt téma iránt érdeklődókkel való párbeszédet értettük, míg külsó kommunikációnak elsôsorban a nyilvánosság erejének a tömegtájékoztatási eszközökön keresztül történő segítségül hívását tekintettük. Ennek alapján a következó civil stratégiák körvonalazódnak:

- Egyes speciális szervezetek valamely meghatározott kör szereplóit (pl. a NIOK esetében a tudományos szférát vagy a civil szervezeteket) próbálják elérni. Számukra a média másodlagos szerepet játszik, de saját projektjeikkel egyes esetekben (pl. a NIOK-nál az Év adományozója- díjak odaítélésekor) megcélozhatják a szélesebb médianyilvánosságot is.

- Az iparági érdekképviseletet ellátó lobbiszervezetek jellemzóen a kormányzattal folytatott párbeszéd közvetítójének és egyúttal egyik fontos résztvevőjének tekintik a médiát. (Számos esetben kiemelték a média hatalmi ágazat jellegét).

- Az alulról szervezódó, illetve kevesebb eróforrással rendelkezô szervezeteknél a médiaszereplés mint a véleményartikuláció egyik lehetôsége és az érdekérvényesítés eszköze kaphat kiemelt szerepet. Az ilyen szervezetek jellemzóen a sok embert érintô, valamilyen közérdekú kérdés körül kialakuló diskurzusok mentén tudnak megjelenni. Ilyen például az önmagát eleve „watchdog” szervezetként definiáló MELASZ, a Technika az Emberért Alapítvány és a NETÉRT. Az ilyen szervezetek tehát céljaik eredeti meghatározásával nem kötődnek szorosan a médiához, de a célok megvalósításában az kiemelten fontos partner számukra, s ez visszahat a szervezet jellegére is.

- Az olyan alulról szervezốdó egyesületek esetében, amelyeknek a tevékenysége a tömegmédia szempontjából túlságosan speciális (pl. MINók) vagy regionális jellegú (pl. HUWICO-Budapest), illetve nem kapcsolódik országos jelentőségú diskurzushoz, az adott szervezet megjelenhet ugyan a médiában és kiépíthet jó médiakapcsolatokat, ami 
jótékonyan hathat a szervezet ismertségére, de a médiaszereplés nem válik a szervezet tevékenységének központi elemévé.

- Egyes alternatív szervezetek (pl. a szabad szoftverekkel foglalkozó, a globalizációellenes és a zöld szervezetek) a tömegmédiával kialakított jó kapcsolataikat is felhasználják stratégiai céljaik elérésére. Ezek a közvélemény támogatását saját músoraik és kiadványaik nyilvános bemutatásán keresztül próbálják megnyerni (jó példa erre a szabad szoftveres szervezetek több rendszeresen megjelenő músora a Fix TV és a Fix Rádió csatornáin vagy a www.indymedia.hu portál). A médiával elsôsorban belsố kommunikációt folytatnak, ki-kikacsingatva a szélesebb nyilvánosság felé.

\section{A vizsgált szervezetek médiareprezentációja}

A médiareprezentáció tekintetében az általunk vizsgált szervezetek az alábbi négy csoportba sorolhatók:

- Egy-egy diskurzus központi szereplő́i. Ezek a diskurzusok jellemzóen valamilyen konfliktushoz kötődnek (BSA, NETÉRT, MTE, LME).

- Jelentốs médiareprezentációjú szervezetek, amelyekkel kapcsolatban folyamatosan jelennek meg különféle cikkek és híradások a médiában (IVSZ, INFÓRUM, Teleház Szövetség).

- Nagyobb projektek kapcsán a média látókörébe került, közepes médiareprezentációjú szervezetek (MINók, NIOK, MATISZ, C3, NJSZT, Zöld Pók Hálózat, INDYMÉDIA, TEA).

- Ritkán és véletlenszerúen megjelenő szervezetek (MIT, MEISZ, HUWICO, FSF, W3C, MELASZ, MEKKE, MKIE, HUNGARNET, HUNINET, ITOSZ, INFOÉRA).

\section{Az illegális szoftver diskurzus}

A nyilvánosság elốtt folyó egyik legnagyobb és legtöbb résztémára bontható informatikai tárgyú vita az elsősorban a BSA tevékenységéhez kötődő illegális szoftver diskurzus. Ez a leghosszabb ideje napirenden levô téma: ezzel kapcsolatban már a kilencvenes évek közepétól kezdve rendszeresen jelennek meg cikkek a szakmai és a napi sajtóban egyaránt. Ugyanakkor ez a diskurzus meglehetốsen kevés ponton és csak közvetve kapcsolódik más témákhoz, és lényegében egyetlen speciális kérdés körül folyik.

A vita kulcsfigurájának a Business Software Alliance nevú szervezet tekinthetô, amelynek a stratégiájához hozzátartozik az illegális szoftver diskurzus folyamatos életben tartása (fizetett hirdetéseken, kutatások eredményeinek ismertetésén és sajtókampányokon keresztül). A diskurzus második részterülete a $B S A$ programjairól való híradás. A harmadik részterületet a rendốrségi akciókról és a folyamatban levố eljárásokról való híradások alkotják, és mindezekre épül rá a $B S A$ tevékenységét vitató ellendiskurzus.

Az illegális szoftverekkel kapcsolatban folyó diskurzusban a felek között a következő fóbb frontvonalak alakultak ki:

A BSA tevékenységének megítélését firtató kérdésünkre adható egyik válasz szerint a $B S A$ független civil szervezet, amely a társadalomban a szoftverek legális alkalmazásáért küzd, és így csak a jogkövető magatartást segíti elő. A másik vélemény úgy fog- 
lalható össze, hogy a BSA célja a szervezetet létrehozó szoftvercégek profitjának maximalizálása, és a $B S A$ - civil szervezeti státusánál fogva - speciális módon befolyásolhatja az állami szerveket. A $B S A$ mint „,civil szervezet” valójában szürke zónát teremt a gazdaság és az állam között, és a „szoftver-rendoórség” szerepében tetszeleg. A BSA „szoftverrendốrségi" funkciójával szemben elvi, jogi és szakmai kifogások merülnek fel. Ezeket a kifogásokat jól demonstrálja, hogy a Technika az Emberért Alapítvány 2002. évi Big Brother-közönségdiját a BSA kapta. ${ }^{3}$

\section{A tartalomszabályozási diskurzus}

A tartalomszabályozásról szóló diskurzus eszkalálódása a 2000-ben Tihanyban tartott Internet Hungary konferenciától eredeztethető, ahol az ORTT részéról felvetették, hogy a tartalomszabályozás kérdését jogi alapokra kívánják helyezni, ami a tartalomszolgáltatók részéról heves ellenkezést váltott ki. Ennek hatására szervezódött meg a Magyarországi Tartalomszolgáltatók Egyesülete, amely mindmáig irányadó szerepet játszik a tartalommal kapcsolatos kérdések megítélésében. Az egyesület azt az álláspontot képviseli, hogy a tartalommal kapcsolatos kérdéseket szakmai önszabályozás útján kell megoldani. A diskurzus azonban a Magyarországi Tartalomszolgáltatók Egyesületének tagjain kívül is sok szereplốt vonultat fel és számos területet érint.

- Idetartoznak mindenekelốtt az internetes tartalmak szabályozásának elvi kérdései, amelyek egy nagyobb problémakörbe illeszkednek és egyrészt az internet mint médium karakterét, szabályozhatóságát vagy szabályozandóságát, másrészt az esetleges szabályozás eszközeit érintik. Ennek a diskurzusnak a keretében más szervezetek képviselói is (pl. Beck György, az Informatikai Érdekegyeztetố Fórum elnöke) mérvadó véleményeket fejtettek ki, a vita folytatódik.

- Ehhez szorosan kapcsolódó terület továbbá az adatvédelem és a szerzói jogok védelme.

- Az adott kérdésben a különbözô politikai pártok eltérô álláspontot fogalmaztak meg. Az informatikai miniszter, Kovács Kálmán például egyértelmúen kijelentette, hogy az IHM nem kíván a tartalmat érintô kérdésekkel foglalkozni.

- Az önszabályozás kérdésében a magyarországi gyakorlat annyi újdonsággal szolgált, hogy a szabályozást - a külföldi példáktól eltérốen - nem az internetszolgáltató, hanem a tartalomszolgáltató végzi.

- A diskurzus utóéletéhez tartozik, hogy Magyarországról több szervezet bekapcsolódott az Európai Unió e-Content programjába, és ennek eredményeként Magyarországon is létrejöttek olyan programok, mint az Infomediátor Iroda, a www.internethotline.hu vagy a Barátságos Internet Fórum.

Magyarországon a tartalomszabályozás kérdései mára tisztázottnak látszanak annyiban, hogy ennek keretrendszerét a szakmai önszabályozás adja és föszereplóje a Magyarországi Tartalomszolgáltatók Egyesülete, ám továbbra is súrún felmerülnek vitás kérdések, mint azt a Hálapénz.hu portál példája is mutatja.

\footnotetext{
${ }^{3}$ A közönségdíj indoklása: „Hatóságnak tünteti fel magát és fenyegetően lép fel a felhasználók ellen, noha csupán egyes szoftvergyártók érdekképviseletére létrehozott nonprofit szervezet.” (Forrás: http://www.bigbrotherawards.hu/vege2002.html)
} 


\section{Az internetelérés költségeivel kapcsolatos diskurzus}

A magyarországi internet penetráció szintje nemzetközi összehasonlításban alacsonyabb a térség helyzete alapján várhatónál, aminek egyik lehetséges okaként többen az internetelérés magas költségeit említik. A vezetékes telefonos internet-hozzáférés egyik alapköve a MindenkiNet díjcsomag volt, ezt a szolgáltatást azonban a Matáv 2002. július 1-jén megszüntette. Két héttel késóbb, július 15-én debütált a Vodafone korlátlan, átalánydíjas GPRS alapú internetszolgáltatása. A Matáv döntésére válaszul megalakult a Netfelhasználók Érdekvédelmi Társasága (NETÉRT), és egy igazán látványos és komoly médiafigyelmet kiváltó akcióval, a 2002. május 25-re „egértemetés” jelszóval tüntetést szervezett. A kérdésben a NETÉRT-en és a Matávon kívül az állam, a politikai pártok és a gazdasági szereplók is állást foglaltak. Néhány hónappal késóbb, 2003 tavaszán az internetezók számának szignifikáns csökkenését kimutató vizsgálat eredményeinek ismertetése, a kormányzat által bevezetett kedvezményes internet-elófizetések bejelentése és a Vodafone szolgáltatásainak korlátozása kapcsán a NETÉRT az internetezók érdekeinek elsố számú képviselôjjeként tudta magát elfogadtatni, és ennek eredményeképpen szinte minden kérdésben azóta is lehetôséget kap a megnyilatkozásra, legyen szó akár gazdasági, akár technikai természetú problémákról.

\section{A szoftverszabadalmakkal kapcsolatos diskurzus}

A médiadiskurzus középpontjában ebben az esetben a szoftvereknek az Európai Unióban megvalósítandó szabadalmaztathatóságával kapcsolatos párbeszéd áll, ami tulajdonképpen a nemzetközi diskurzus leképezôdésének tekinthetố: a témában kibocsátott irányelvekkel kiváltott viták arról folynak, hogy - az Egyesült Államokhoz hasonlóan, ahol már évek óta megvan egyes technológiák (például egyes honlapokon bizonyos fajta navigációs lehetôségek) szabadalmaztatásának a lehetôsége - ennek Európában is meg kell-e teremteni a jogi alapjait. A független fejlesztố csoportoknak és a szabad szoftverek híveinek álláspontja szerint az ilyen típusú szabadalmak megbénítják a versenyt és az innovációt, és az amúgy is elônyös helyzetben lévố multinacionális szoftvercégeket segítik. Az ehhez kapcsolódó magyarországi diskurzusban ritkaságszámba menó módon - a civil szektor prominens képviselóit tömörítô, rendkívül széles körú összefogással kibontakozó alkalmi szövetség jött létre a direktíva ellen, amelynek a tagjai között szerepel a Free Software Foundation, a Linux-felhasználók Magyarországi Egyesülete, a Magyar Tartalomipari Szövetség és az Informatikai Vállalkozások Szövetsége is. Néhány informatikai vállalkozás (UHU-Linux, LSC, Publishing Factory, Balabit és a többiekhez képest mamutnak számító Novell) szintén hallatta a hangját. A tiltakozás nagyrészt nyílt levelek megfogalmazásából állt, azonban nem érte el a tömegsajtó érzékenységi küszöbét, inkább a szakmai sajtó követte az eseményeket a szervezetek és a vállalatok által kiadott közlemények megjelentetésével.

Ezzel szemben a szabadalmak ellen tiltakozó demonstráció, amihez további szervezetek is csatlakoztak, már kelló súllyal szerepelt a mainstream médiában, ahol folyamatosan napirenden tartották a kérdést. 
A vita bizonyos tekintetben a tiltakozók gyốzelmével látszik zárulni: mind az Európai Unió, mind a magyar kormány illetékes köreiben megoszlanak a vélemények a kérdésben, és ez a helyzet - egyelöre úgy túnik - a jelenlegi rendszer fennmaradásának kedvez.

A civil szféra strukturális meghatározottsága

Az általunk vizsgált szervezetek jellegét a következố tényezók határozzák meg: a szervezet által igénybe vehetố erooforrások, a saját maga számára meghatározott tevékenység és az adott diskurzus, a szervezet múködési környezete. Az alábbiakban ezeket a kérdéseket vizsgáljuk meg röviden.

\section{Az erőforrásokhoz való hozzáférés}

Az elsố tényezóként megnevezett eróforrások viszonylag könnyen azonosíthatók voltak, annál is inkább, mivel itt - kissé leszúkítve - csak az anyagi, humán és infrastrukturális feltételeket vizsgáltuk. Az eróforrások szempontjából a szervezeti múködés lehetôségei túnnek a vízválasztónak, vagyis az, hogy az egyes projektekre kapott pénzösszegek felhasználásán kívül mennyire biztosított maga a szervezeti lét, továbbá fontos szerepet játszik a szervezet nagysága is. Az iparági érdekképviseletek, a költségvetési szervekhez valamilyen módon kötốdố csoportok és az alulról jövố kezdeményezések között döntő különbségek vannak.

Az iparági érdekképviseletek létrehozói valamilyen formában biztosítják a szervezetek múködési feltételeit mind anyagi, mind infrastrukturális és humán oldalról. Ugyanakkor megállapítható, hogy ezeknél a szervezeteknél a tagok és a tisztviselók sokszor fizetés fejében végzik a munkájukat: a civil szektorra jellemzô önkéntesség szintje itt a legalacsonyabb.

A költségvetési szervekhez kötődő NGO-k (pl. HUNGARNET, HUNINET, ITOSZ, $M E K K E$ ) a humán tókén kívül viszonylag jól tudják biztosítani az infrastrukturális hátteret is. Jellemzó rájuk, hogy a szervezeti tevékenység során adódó feladataikat a tagok (pl. azok az egyetemi oktatók, akik részt vesznek a HUNINET tevékenységében is) valamilyen intézmény alkalmazásában végzett munkájuk mellett látják el.

Végül az alulról jövó civil kezdeményezések vannak a legbizonytalanabb helyzetben mind az infrastrukturális háttér, mind a pénzalapokhoz való hozzáférés tekintetében: legfontosabb eróforrásuk a tagok által többnyire önkéntesen végzett munka.

Elôfordul ugyan, hogy egyes szervezetek múködési költségeik fedezetének biztosítására bizonyos szolgáltatásokat nyújtanak és az így keletkezett bevételt visszaforgatják a szervezet tevékenységébe, de az általunk vizsgált szervezetek körében ez korántsem nevezhetố tipikusnak.

\section{A szervezet feladatainak természete és a szervezet bekapcsolódása a társadalmi diskurzusokba}

A szervezetek tevékenyégét illetôen hasznos megkülönböztetési szempontnak túnik, hogy az adott szervezet életében milyen arányban áll egymással a szervezet saját hatáskörében végzett munka (belsố aktivitás) és a szervezet tevékenységi körét érintô 
társadalmi diskurzusok alakítása (külső aktivitás). A diskurzus ebben az esetben a valamely fontos társadalmi kérdéssel kapcsolatos összes releváns közéleti megnyilvánulást jelenti, tehát az adott kérdésnek a médiában való megjelenésén kívül idetartoznak a politikai döntések, a törvényhozói munka és a szervezetek között, illetve azokon belül folyó egyeztetések is. A kutatás során készített interjúk alapján a vizsgált szervezetek szempontjából a következő diskurzusok bizonyultak a legfontosabbnak :

$\mathrm{Az}$ információs társadalommal kapcsolatban folyó mainstream diskurzus valójában több diskurzus egymásba fonódása, amelyek az úgynevezett „legjobb gyakorlatokat” (best practices) és a résztvevók véleménye szerint célravezetố stratégiákat járják körül, s ,az információs társadalom fejlesztése Magyarországon" címszó alatt foglalhatók össze. Ennek a sokrétú diskurzusnak olyan kristályosodási pontjai vannak, mint a penetráció, az e-közigazgatás, az eszközökhöz való hozzáférés támogatása, az ágazati támogatások elosztása, a K+F tevékenység élénkítése, valamint az eszközök és a szolgáltatások árszínvonala. Jellemzố a diskurzusra, hogy az egész magyar lakosságot érintố kérdéseket tárgyal a legszélesebb médianyilvánosság elő́tt, szakmai, tudományos és gazdasági megfontolások szerint. Legfóbb témája az, hogy az állami szerepvállalás milyen módon teremthet ideális feltételeket a fejlödéshez. A diskurzusban részt vesz az összes szakmai és ágazati érdekképviseleti szervezet, továbbá az MIT, az egyik legrégebbi szervezet, amely elsősorban az internettel foglalkozik.

A szervezetek másik csoportja ,alternatív” megközelítéssel, sajátságos nézôpontok felól próbálja az általa képviselt értékeket artikulálni. Ilyenek pl. a szabad szoftverekkel foglalkozó egyesületek, a privacy kérdéseire koncentráló Technika az Emberért Alapítvány, a zöld szervezetek, a globalizációellenes mozgalmak és a MINók .

A szervezetek következố csoportját azok alkotják, amelyek kevésbé foglalkoznak az össztársadalmi érdekú kérdésekkel. A médianyilvánosság ezeknek az esetében elsốsorban az általuk végzett munka szempontjából lehet fontos. Idetartoznak a tudomány világához és az egyházakhoz kötôdő, valamint a civil társadalom fejlesztésével, illetve a múvészeti és oktatási tevékenységgel foglalkozó szervezetek. Ezek csak bizonyos esetekben fordulhatnak a médiához: ismertségük nyilvánvalóan befolyásolja ezeknek a szervezeteknek a lehetôségeit is, de ez számukra az alaptevékenységükhöz képest csupán másodlagos fontosságú.

Az ebbe a csoportba tartozó szervezetek közül kiemelhetố a Teleház Szövetség és az Intelligens Települések Országos Szövetsége, amelyek azért különlegesek ebben a körben, mert fö tevékenységük folytatása mellett egyre inkább az információs társadalom komplex problémakörének egészét átfogó központi diskurzus irányába mozdulnak el. Ezek egyrészt társadalmi súlyuk révén kerülnek be a mainstream diskurzusba, másrészt pedig azért, mert Magyarországon az információs és kommunikációs technológiai eszközökhöz való közösségi hozzáférés és az e-közigazgatás programjait a kormányzati politika az információs társadalomhoz vezetố út kiemelt stratégiai fontosságú állomásaiként határozta meg.

\section{A szervezetek működési környezete}

A szervezetek múködését meghatározó harmadik tényező az, hogy milyen nagyobb hálózatba illeszkednek bele, ugyanis - mivel a hálózatoknak legalábbis az informális eróforrásai valamilyen mértékig a hozzájuk kapcsolódó szervezetek számára 
is elérhetôvé válnak - a hálózatok prioritásai és normái befolyásolják a szervezetek munkáját.

Az információs társadalom kialakulásával összefüggő kérdésekkel foglalkozó szervezetek legmarkánsabb csoportját a szakmai és az ágazati képviseleti szervezetek alkotják. Ezeknek az eróforrásait túlnyomórészt az alapítóik biztosítják. Az idesorolható szervezetek jellemzốen professzionális munkát végeznek, vagyis a gazdasági hatékonyságra való törekvés egyes elemei megjelennek a szervezetek múködésében is.

A költségvetési intézmények civil szervezetei a magyarországi NGO-k világában sajátos szigetet jelentenek: rendelkeznek infrastruktúrával és információkkal, és az ágazati képviseletekhez hasonlóan átültetik munkakultúrájukat a szervezet múködésébe. Önmeghatározásukban általában élesen elhatárolják magukat a „valódi” civil szervezetektól. Tevékenységük többnyire valamilyen speciális funkció „kiszervezéseként” is értelmezhetô.

A következô csoportként a nemzetközi szervezetek magyar fiókszervezetei nevezhetốk meg. Ezekre jellemző, hogy a hazai civil szféra zöméhez képest bizonyos mértékig kitüntetett helyzetben vannak, mivel múködésükben - és adott esetben múködési feltételeikben is - a nyugati normák, eljárások és standardok érvényesülnek, és részben ennek köszönhető́n többnyire sokkal jobban definiált célok eléréséért munkálkodnak. Idesorolható a $B S A$, a $M I T$, a $W 3 C$, és bizonyos értelemben a NIOK és a $C 3$ is. ${ }^{4} \mathrm{~A}$ jó nemzetközi kapcsolatok megléte leginkább az adott NGO-k szervezeti kultúrájára hat ki, de ezeknek a kapcsolatoknak más hozadékai is lehetnek. A szabad szoftverekkel foglalkozó, a globalizációellenes és a zöld mozgalmak nagy része szintén nemzetközi szervezetek „honosításaként” jött létre, ez utóbbiaknak a múködésében azonban kevésbé érvényesülnek a fent jelzett hatások.

\section{Összefoglalás}

\section{A civil szféra vizsgált szegmentumára általában jellemző vonások}

A kutatás során vizsgált NGO-k sajátosságai elsốsorban az információs társadalom (és a vele kapcsolatos diskurzus) fejlődésének jelenlegi magyarországi szintjét tükrözik. Ugyanakkor jellemzó, hogy ezek a szervezetek - annak megfelelóen, hogy az információs társadalom fogalmát hogyan értelmezik - eltérô mértékben elkötelezettek az információs társadalom „ügye” mellett. Az információs társadalom kiépítésével kapcsolatos különféle felfogások spektrumának egyik végpontját jelentố „minimális program” kimerül az infokommunikációs eszközök pragmatikus használatában, a másik végponton elhelyezkedő „maximális program” pedig egy olyan jövő víziója, amelyben a társadalmat konstituáló kommunikáció túlnyomórészt az új típusú infokommunikációs eszközökön keresztül zajlik, amelyek ezáltal a társadalom elsődleges strukturáló tényezóivé válnak. Az „információs társadalom” kifejezés értelmezési tartományának egyik legfontosabb jellemzóje a fogalom általános jellegéból adódik: a fogalom nem lokalizálható je-

\footnotetext{
${ }^{4}$ Bizonyos szempontból a Soros Alapítvány is felfogható ilyen közvetítő hálózatként, ezért a NIOK-on keresztül áttételesen más szervezetek is idesorolhatók.
} 
lenségekre vagy jelenségek csoportjaira, hanem átfogó folyamatokra utal, amelyek átalakítják az egész társadalom, s azon belül elsốsorban a politikai és a gazdasági alrendszerek múködését. Ennek megfelelően az információs társadalom kiépítésének kérdéseiben mind az állami és politikai szféra, mind az átalakuló gazdaság szereplôi közvetlenül érintettek és érdekeltek. Az információs társadalom „ügye” tehát elsốsorban az állam és a gazdaság cselekvési programjaként jelenik meg, s emiatt a civil szférában ezekkel a kérdésekkel foglalkozó szervezetek többségét - a politikai orientációjú csoportok mellett - a gazdasági szereplóket és a valamilyen módon mindig az államtól függố közintézményeket képviselő NGO-k teszik ki, s ezek tekinthetốk a legmeghatározóbbaknak.

A másik legfontosabb általánosan jellemzố vonás az, hogy Magyarországon az információs társadalom kiépítése úgy jelenik meg, mint olyan befektetés a jövóbe, ami a most elterjedő technológiákhoz kötődik. Az információs társadalommá való átalakulás Magyarországon elsốsorban a jövốre vonatkozó stratégia megtervezését és megvalósítását jelenti. Az információs társadalom diskurzusában részt vevố civil szereplók elsốsorban az információs társadalom kialakításában érdekelt csoportok (pl. iparágak), valamint az „ügyben” speciális módon érintett foglalkozási körök képviselói közül kerülnek ki. (Meg kell jegyezni azonban, hogy itt is hatnak a digitális szakadék egyenlốtlenségei.)

A harmadik fontos jellemzố vonásnak azt tekinthetjük, hogy míg az internet lehetôséget teremt számos kapcsolat kialakulására és az önszervezódési lehetôségek soha nem látott bőségét teremti meg, az interneten keresztül szerveződött közösségek sok esetben csak online „élnek”, miközben offline nem intézményesülnek. Ugyanakkor az offline intézményesülő szervezetekre is jellemző az infokommunikációs eszközök intenzív használata, tehát valószínúsíthetô, hogy a civil szférának az a része, amely az információs társadalom körül pulzál, valójában sokkal kiterjedtebb és összetettebb annál a vékony szeletnél, ami a látókörünkbe kerül, csak az intézményesülés híján sokszor észrevétlen marad.

\section{A vizsgált szervezetek csoportosítása}

Mindezek után talán nem meglepó az a megállapítás, hogy a vizsgált szervezeteknek a különféle eróforrásokhoz való hozzáférése, múködési környezete és tevékenysége szempontjából egyaránt a legtöbbet eláruló és a leginkább meghatározó tényezốnek azt tekinthetjük, hogy a szervezet milyen módon kötốdik (vagy egyáltalán kötődik-e) valamely másik társadalmi alrendszer szereplóihez.

Ennek megfelelốen a legjelentôsebb és leginkább meghatározó csoportnak a gazdasági szervezeteket tömörítő, iparági érdekvédelmi szervezetek (IVSZ, MATISZ, MEISZ, MTE, MELASZ) tekinthetók, természetesen idesorolva az ezeket tömörítố INFÓRUM-ot is. Ezeket a szervezet múködéséhez szükséges eróforrásokhoz való jó hozzáférés és a súrú szervezeti hálóba való beágyazódás, valamint az ezzel együtt járó intenzív belsó kommunikáció jellemzi. Ezek a szervezetek elsôsorban a szabályozók kialakításában és a keretfeltételek megtervezésében vesznek részt, és élénk kommunikációt folytatnak a kormányzattal. 
A második legfontosabb csoportba az államhoz és a tudományos szférához kötődô civil szervezeteket sorolhatjuk. A két típus összevonását az indokolja, hogy mind az önkormányzatok, mind a tudományos szféra intézményei a központi költségvetéstól függnek. Az idetartozó szervezetek többnyire a költségvetési intézmények egyes feladatait látják el civil szervezeti formában (pl. HUNINET, HUNGARNET, MEKKE), vagy a közigazgatás alacsonyabb szintjén elhelyezkedő szervezeteket fogják össze és képviselik az országos diskurzusban (pl. ITOSZ).

Az alrendszerekhez nem kötôdő civil szervezetek jellegzetes csoportja elsốsorban a nagy nemzetközi hálózatok magyar tagszervezeteiból tevődik össze.

Az alulról jövố civil kezdeményezések körében nagy változatosság tapasztalható: ezek közé sorolható az országos ismertségú Netfelhasználók Érdekvédelmi Egyesülete (NETÉRT), de akadnak közöttük az információs társadalom diskurzusához közvetlenül kapcsolódó és annak alternatív olvasatait nyújtó szervezetek (ilyen például a Privacy Internationalhez kötődő'Technika az Emberért Alapítvány és a Magyar Internetezô Nók Egyesülete), a tudatformálás küldetését vállaló szervezetek (MKIE, MIT) és a kifejezetten valamilyen speciális tevékenység támogatására szervezôdött NGO-k (pl. HUWICO, INFOÉRA) is.

Az alulról szerveződó NGO-k közé tartoznak az említetteken kívül az információs társadalom diskurzusához csak érintólegesen kapcsolódó rendszerkritikai (globalizációellenes és zöld) mozgalmakat képviselố szervezetek is (Zöld Pók Hálózat, Indymedia.hu).

Az iparági képviseleti szervezetektôl az alulról szerveződő kezdeményezésekig terjedő spektrum középső részén helyezkednek el a szoftverek szabad felhasználásáért küzdő szervezetek, amelyek közül mi a Linuxfelhasználók Magyarországi Egyesületét és a Free Software Foundation magyar fiókszervezetét kerestük meg.

Az eddig kialakított kategóriákba három szervezet nem túnik besorolhatónak:

- A civil szervezeti státust kategorikusan elutasító $B S A$ önmagát mint „szoftverrendốrséget" definiálja.

- a Magyarországon legrégebben múködő informatikai szervezet, a Neumann János Számítógép-tudományi Társaság (NJSZT) sajátos hungarikumnak tekinthetố, egyrészt azért, mert az informatikával foglalkozó magyar szakemberek és az informatika iránt érdeklődô laikusok közötti kapcsolatok ápolására vállalkozik, másrészt pedig azért, mert Magyarországon ez a szervezet vállalja a felelósséget az ECDL vizsgaközpontok akkreditációjáért.

- Ha a Neumann János Számítógép-tudományi Társaságot hungarikumnak nevezhettïk, akkor a Teleház Szövetség a magyar specialitások egy további „fokozatának” tekinthetó, hiszen a skandináv országokból kiindult Teleház mozgalom körein belül ma már „magyar modellrốl" beszélnek. A szervezet egyedülálló fejlettségét jól mutatja, hogy a több mint 500 teleházat tömörítô szövetség a közösségi internet-hozzáférési és vidékfejlesztési diskurzus középpontjába került.

Ha végiggondoljuk a kutatás révén felszínre hozott összefüggéseket, a következtetések két irányban túnnek továbbgondolhatónak. Egyrészt mérlegelhetjük, hogy a Wilson-modell mennyire alkalmas a magyarországi viszonyok leírására, másrészt rögzíthetjük a Magyarországra jellemzố sajátosságokat. 
A modell továbbgondolásával kapcsolatban határozottan kirajzolódni látszik, hogy az általunk vizsgált szervezetek esszenciális értelemben nem mind sorolhatók a „civil szféra” kategóriájába. Annál is kevésbé, mivel az egyes szervezetek jellemzố vonásainak a végsố kategorizálása során a társadalmi alrendszerekhez való kapcsolódás bizonyult a leginkább meghatározó tényezốnek. A vizsgált szervezetek esetében tehát két fố típus látszik megkülönböztethetốnek. Az egyikbe azok a szervezetek tartoznak, amelyek a nagy alrendszerek és cselekvési-kommunikációs szférák közötti, illetve azokon belüli közvetítés feladatait látják el (ennek a típusnak jellegzetes példái a gazdaság és a politika között közvetító iparági érdekérvényesítô szervezetek, továbbá a központi kormányzat, a politikai erók és az önkormányzatok között lavírozó Intelligens Települések Országos Szövetsége, vagy a tudományos szféra, a gazdaság és az állam közötti alkufolyamatokat menedzselő Hungarnet és Huninet). A másik típushoz azok a szervezetek tartoznak, amelyek ténylegesen valamilyen alaptevékenységet végeznek, és kapcsolataikat csak ezek támogatására használják (például a Magyar Elektronikus Könyvtárért Közhasznú Egyesïlet vagy a Huwico). Ezeknek a szervezeteknek a kapcsolatait közelebbról szemügyre véve azt láthatjuk, hogy noha maguk a szervezetek nem kötôdnek egyértelmúen egyik nagyobb alrendszerhez sem, kapcsolataikat elsôsorban az állami-politikai szférával alakítják ki.

Ezzel a Wilson-gyémánt aktorainak vizsgálatában áttértünk a magyarországi sajátosságok vizsgálatára. Konklúzióként leszúrhetjük, hogy a legtöbb „tengellyel” (és egyben a legerôsebbekkel) az állami-politikai szféra rendelkezik, ami ezen az alapon „fejnehéznek” mondható, s ehhez képest a többi szféra kapcsolatai jellemzóen egycsatornásak, és ráadásul azok is elsốsorban az állammal kommunikálnak. Mindez együttvéve a Wilson-modellben a „modernizálódó társadalom” korábbi fejlódési szakaszának felel meg.

Az elmondottak alapján a következő kérdések fogalmazhatók meg: Mennyire tekinthetjük érvényesnek azt az állítást, hogy Magyarországon még korántsem fejezôdött be a modernizálódás, és mit jelent ez pontosan? Hol tart Magyarország a modernizálódásban? Miben tér el Magyarország „,fejlettségi szintje” más társadalmakétól? Van-e általánosan alkalmazható recept, illetve hogyan határozható meg az a külön út, amelyet követve sikeresen végigjárhatók a modernizálódás lépcsófokai?

További kérdés, hogy azok a „civil” szervezetek, amelyek elsősorban közvetítố szerepet látszanak betölteni, beilleszthetốk-e valamilyen módon a wilsoni gyémántmodellbe. Az ilyen szervezetek vajon csak a modernizáció elótti kezdetleges magyarországi viszonyok sajátosságait tükrözik, vagy pedig a modell alkalmazhatóságának egyik speciális határterületét képviselik?

\section{Az interiúk készítése során felkeresett szervezełek jegyzéke}

BSA Magyarország

C3 Kulturális és Kommunikációs Központ

Free Software Foundation Hungary Alapítvány (FSF)

HUNGARNE'T Egyesület

HUNINET (Hungarian University Network) 
HUWICO (Hungarian Wireless Community)

Independent Media Center Magyarország (Indymedia)

INFO-ÉRA Alapítvány

Informatikai Érdekegyeztetô Fórum (INFORUM)

Informatikai Vállalkozások Szövetsége (IVSZ)

Intelligens Települések Országos Szövetsége (ITOSZ)

Linux-felhasználók Magyarországi Egyesülete (LME)

Magyar Elektronikai és Infokommunikációs Szövetség (MEISZ)

Magyar Elektronikus Aláírás Szövetség (MELASZ)

Magyar Elektronikus Könyvtárért Közhasznú Egyesület (MEKKE)

Magyar Internet Társaság (MIT) ${ }^{5}$

Magyar Internetezố Nók Egyesülete (Minók)

Magyar Keresztény Internet Egyesület (MKIE)

Magyar Tartalomipari Szövetség (MATISZ)

Magyarországi Tartalomszolgáltatók Egyesülete (M'TE)

Magyar Teleház Szövetség Egyesület

Netfelhasználók Érdekvédelmi Társasága (NETÉRT)

Neumann János Számítógép-tudományi Társaság (NJSZT)

Nonprofit Információs és Oktató Központ (NIOK)

Technika az Emberért Alapítvány (TEA)

World Wide Web Consortium (W3C) Magyar Iroda

Zöld Pók Hálózat

\section{Irodalom}

Ernest J. Wilson III (2003): Leadership for a networked world. Background paper for Development. Gateway Forum. Petersberg, Germany: May 21. 2003.

Juhász Lilla (2004): Predigitális harmadik világ. A fejlődő országok az információs társadalom korszakában: realitások és lehetôségek. Egyenlító, 3.

Juhász Lilla (2004): Elméleti széljegyzetek a predigitális harmadik világ gondolatköréhez. Egyenlitó, 5 .

Juhász Lilla: Internet, kapitalizmus és új baloldal. Egyenlitóo. Megjelenés alatt.

Kollányi Bence - Molnár Szilárd - Z. Karvalics László (2004): A BME ITTK éves jelentése a magyar információs társadalomról 2004-ben. Magyar Információs Társadalom Stratégia. MITS 1076.

Kondorosi Ferenc (1998): Civil társadalom Magyarországon. Budapest: Politika és Kultúra Alapítvány.

Kuti Éva (1998): Hívjuk talán nonprofitnak... Budapest: Nonprofit Kutatócsoport.

László János (2000): A szociális reprezentációról. In: Társadalmi kommunikáció. Szerk. Béres István - Horányi Özséb. Budapest: Osiris, 129-138.

László János (2002): Pszichológia, irodalom, elbeszélés. In: Az általánostól a különösig. Szerk. Czigler István - Halász László - Marton M. Magda. Budapest: Gondolat Kiadói Kör: MTA Pszichológiai Kutatóintézet, 317-336.

\footnotetext{
${ }^{5}$ Az ISOC (Internet Society - ld. http://www.isoc.org) magyar tagozata.
} 
László János - Ehmann Bea - Péley Bernadette - Pólya Tỉbor (2000): A narratív pszichológiai tartalomelemzés: Elméleti alapvetés és első eredmények. Pszichológia, 4. 367-390.

Peter Levine (2004): The Internet and Civil Society. In Verna V. Gehring (ed.): The Internet in Public Life. Rowman \& Littlefield, 79-98. (Magyarul: Peter Levine (2005): Az Internet és a civil társadalom. Információs Társadalom, 1.

Molnár Szilárd (2004): TV, Internet, civil társadalom. Előadás a Rajk László Szakkollégium „Társadalmi mozgalmak és online közösségek” c. konferenciáján. Budapest: 2004. február

Nyíri Kristóf (1999): Castells - The Information Age. Replika, 36, 157-181.

http://www.c3.hu/scripta/replika/36/13nyiri.htm)

Péterfi Ferenc (2004): A közösségi akarat esélyeiról. Parola, 3.

Pintér Róbert (2003): A globális információs társadalom: Castells - The Information Age. Jel-Kép, 3. 